taste. (e) Sea-water drinking. (f) Craving for ice-a form of pica.

8. (a) Buddenbrooks. (b) Dr. Faustus. (c) The Magic Mountain. (d) The Black Swan.

9. (a) A tick-borne protozoal infection which has been reported in splenectomized individuals. (b) Infectation with the gapeworm, which lives in respiratory tract of animals in the tropics. (c) Infestation with larval cyst of dog tapeworm. (d) Infection due to encephalitozoon causing disease in bees and silkworms, and rarely in man. (e)
Common nematode infestation in cattle which may cause protein-losing enteropathy.

10.1886.

11. (a) 1923; (b) $9 \mathrm{~s}$.

12. Establishment of Ministry of Health.

13. Department of Education and Science.

The photograph of Worcester Royal Infirmary is by Geoffrey N. Hopcroft, Worcester, that of Birmingham and Midland Hospital at Southwark by Handford Photography, Croydon.

\title{
PARLIAMENT
}

\section{Employment Medical Advisory Service}

On 13 December Mr. Dudley Smith, Under Secretary for Employment, moving the second reading of the Employment Medical Advisory Service Bill, said the Bill was to establish an employment medical advisory service and took an important step forward in occupational medicine.

\section{Routine Examinations to be Abolished}

Today, he said, young persons entering factory employment had to be medically examined within 14 days and annually until they were 18. These examinations were carried out by some 1,500 appointed factory doctors. The School Health Service and the N.H.S. now kept a careful check on the health of young persons and routine examinations by factory doctors had ceased to be so important. The report of a subcommittee of the Industrial Health Advisory Committee in 1966 considered that the requirement for routine examination of young persons entering factory employment should be abolished and that a more integrated and expert medical service, with wider duties in occupational medicine, should be established.

\section{One Nation-wide Organization}

The Bill implemented and developed these recommendations. The nucleus of the new service would be the recently formed Medical Services Division of the Department of Employment, which advised other branches of the department on medical prob- lems arising from employment, including fitness for work, placement, industrial rehabilitation, and mental health. When the Employment Medical Advisory Service was established there would be added to these duties the medical supervision of young persons in employment and the examination of workers in hazardous trades. This would bring together in one nation-wide organization the various categories of doctors employed in industrial medicine. The Government would seek to identify and overcome the causes of disease, fatigue, and stress arising from work. It was intended that the service should tap the expertise of many disciplines.

\section{Staffing of the New Service}

The nucleus of the new service would be the 50 doctors already employed by the Department of Employment and the equivalent of 50 more full-time doctors, 35 in the first year, building up to 50 when the service was at full strength, together with supporting staff. It was also proposed to bring 12 nurses into the service.

\section{Industrial Safety not Included}

Mr. Harold Walker (Doncaster, Lab.) said that his welcome for the Bill was cooled by the absence from it of anything which dealt directly and specifically with industrial safety. The Government had not provided for worker representation and safety committees.
Dr. David Owen (Plymouth, Sutton, Lab.) emphasized the importance of specific occupational health training for the doctors and nurses who were to work in the service.

Dr. Alan Glyn (Windsor, Con.) said that a close liaison between a medical advisory service in an industry and a family doctor would produce the best possible service for the individual patient.

\section{Government Reply}

Mr. Dudley Smith, in the course of his reply to the debate, agreed that industrial safety was not mentioned in the Bill. The Government had thought it right that the subject matter of the Bill should be judged and provided for separately. The service would be concerned in quite a big way with disabled people. The laboratory services would be provided by its own central laboratory and by designated N.H.S. laboratories and it would co-operate with the university departments. A number of the full-time doctors would be works medical officers, some would be ex-appointed factory doctors. They would not be withdrawn from the N.H.S. Pay for the doctors would be the standard salaries for the various grades of medical civil servants. There would be a career structure which should be attractive to good men. The service was expected to be headed by Dr. T. A. Lloyd Davies, the department's chief medical adviser.

The Bill was read a second time.

\section{MEDICAL NEWS}

\section{Seminars at B.M.A. House}

A seminar on urinary problems will be held at B.M.A. House on Friday 28 January from 10 a.m. to 5 p.m. For details see advertisement on page vi.

\section{Cyprus Congress: Closing Date for} Registration

The closing date for advance registrations for the East Mediterranean Medical Congress Cyprus, 11 to 15 April 1972, is 31 December 1971 (see Supplement, 27 November, pp. 45-8 for programme).

\section{COMING EVENTS}

Nuffield Department of Orthopaedic Surgery, Oxford University.-Series of lectures, the second half of a postgraduate course "Basic Sciences of the Musculoskeletal System," Friday evenings, 6.30 p.m., and Saturday mornings,
8.30 a.m., 7 January-11 March inclusive Nuffield Orthopaedic Centre, Oxford. Members of the medical and allied professions are invited.

\section{SOCIETIES AND LECTURES}

For attending lectures marked * a fee is charged or a ticket is required Applications should be made first to the institution concerned.

Thursday, 30 December

London Jewish Hospital Medical Society.-A 11 Chandos Street, W.1, 8.15 p.m., annual oration y Professor W. W. Mushin: The Craftsman in

Friday, 31 December

Royal Postgraduate Medical SCHOOL.-11 a.m.
Professor M. Foldi:

\section{Corrections}

Transport to the Surgery

There was an error in the fifth line of the third paragraph of the leading article on this subject (18 December, p. 697). The affected sentence should have read: "The Scottish rural practice offered transport only to one tenth of those asking for home visits and nearly all accepted it, while the other three offered the service to half, of whom half accepted it."

\section{Notice to Authors}

When original articles and letters for publicatinn are not submitted exclusively to the British Medical fournal this must be stated.

Correspondence on editorial business should be addressed to the Editor, British Medical Fournal, B.M.A. House, Tavistock Sauare, London WC1H 9JR. Telephone: 01-387 4499. Telegrams: Aitiology, London, W.C.1.

Authors wanting reprints of their articles should notify the Publishing Manager, B.M.A. House, Tavistock Square, WC1H 9JR, on receipt of proofs. 